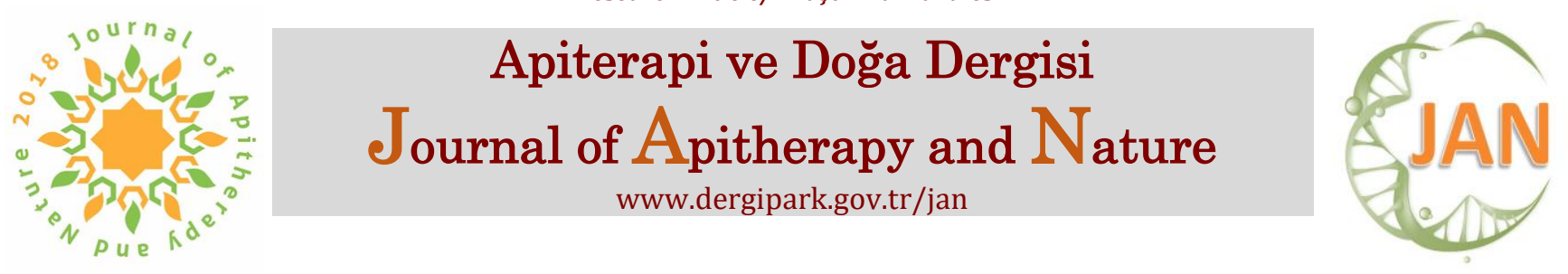

\title{
Antioxidant Capacity of a Bee Pollen Sample Obtained from Giresun, Turkey
}

\section{Giresun, Türkiye’den Elde Edilen Aru Poleni Örneğinin Antioksidan Kapasitesi}

\author{
Huseyin SAHIN', Mehmet KEMAL ${ }^{2 *}$ \\ ${ }^{1}$ Espiye Vocational School, Giresun University, Giresun, Turkey \\ huseyin.sahin@giresun.edu.tr, ORCID: 0000-0002-6018-1494 \\ ${ }^{2}$ Department of Nutrition \& Dietetics, Faculty of Health Sciences, Artvin Coruh University, Artvin, Turkey \\ *mkemal@artvin.edu.tr, ORCID: 0000-0003-2561-807X
}

Received/Geliş Tarihi: 14/02/2020, Accepted/ Kabul Tarihi: 11/03/2020 *Corresponding author / yazışılan yazar

\section{Abstract}

This study was related to evaluating the antioxidant of one pollen sample which was collected from Giresun, Turkey. The antioxidant properties of this sample were determined to use total phenolic contents (TPCs), total flavonoid contents (TFCs), proanthocyanidin contents (PCs), and ferric reducing antioxidant power (FRAP) assays. The result of the total phenolic content was $6.33 \pm 0.11 \mathrm{mg} \mathrm{GAE} / \mathrm{g}$ sample, total flavonoid content was $1.88 \pm 0.11 \mathrm{mg} \mathrm{QE} / \mathrm{g}$ sample, proanthocyanidin content was $0.86 \pm 0.00$ $\mathrm{mg} \mathrm{CE} / \mathrm{g}$ sample, FRAP was also $72.38 \pm 0.21$ $\mu \mathrm{moL} \quad \mathrm{FeSO}_{4} .7 \mathrm{H}_{2} \mathrm{O} / \mathrm{g}$, respectively. The obtaining results revealed that the pollen could be seen as a valuable natural source thanks to its significant antioxidant capacity.

Keywords: Bee-pollen, Antioxidant, Total phenolic content, Total flavonoid content, Proanthocyanidin content doi: $10.35206 /$ jan.689291 e-ISSN: 2667-4734

Abbreviations: TPC, Total phenolic content; GAE, Gallic acid equivalent; TFC, Total flavonoid content; PC Proanthocyanidin content; FRAP, Ferric reducing antioxidant power

\section{INTRODUCTION}

Turkey is one of the leading countries in terms of the apiculture, which is an occupation with bee products such as honey, beebread, bee venom, bee pollen, propolis, and royal jelly, thanks to its

\section{Özet}

Bu çalışma, Türkiye'nin Giresun ilinden temin edilen bir arı poleni örneğinin antioksidan değerlendirilmesi ile ilgilidir. Çalışılan polenin antioksidan özelliği, toplam fenolik madde (TPC), toplam flavonoid madde (TFC), proantosiyanidin içeriği (PC) ve demir indirgeyici antioksidan güç (FRAP) metotları kullanılarak tayin edilmiştir. Sonuçlar sırasıyla, toplam fenolik içeriği $6,33 \pm 0,11 \mathrm{mg} \mathrm{GAE} / \mathrm{g}$, toplam flavonoid içeriği $1,88 \pm 0,11 \mathrm{mg} \mathrm{QE} / \mathrm{g}$, proantosiyanidin içeriği $0,86 \pm 0,00 \mathrm{mg} \mathrm{CE} / \mathrm{g}$ ve FRAP metodu da 72,38 $\pm 0,21 \quad \mu \mathrm{moL}$ $\mathrm{FeSO}_{4} .7 \mathrm{H}_{2} \mathrm{O} / \mathrm{g}$ idi. Elde edilen sonuçlar, önemli antioksidan kapasitesinden ötürü arı poleninin değerli bir doğal kaynak olarak görülebileceğini ortaya koymuştur.

Anahtar kelimeler: Ar1 poleni, Antioksidan, Toplam fenolik içerik, Toplam flavonoid içerik, Proantosiyanidin içerik 
Gan, 2017; Sahin, 2016). Especially, bee-pollen collected by honey bees is one of these products and acts as a natural warrior against some diseases. This warrior characteristic of bee pollen comes from some bioactive compounds such as polyphenol substances which are responsible for the potent antioxidants.

In the literature, there have been so much considerable researches on the biological activity of bee pollen. But, it could be seen as limited in terms of the location because it was emphasized as Giresun, Turkey. Hence, the aim of the current study is to determine the antioxidant activity of a local bee pollen sample supplied from Giresun, Turkey with some different assays.

\section{MATERIALS AND METHODS}

\subsection{Sample Collection}

Pollen sample was supplied from a beekeeper at the season of 2019 in Giresun, Turkey. The sample was stored at $+4^{\circ} \mathrm{C}$ in dark plastic containers until analyzed on the instruments.

\subsection{Extraction Procedure}

For all experiments, approximately $10 \mathrm{~g}$ of pollen sample was extracted with $50 \mathrm{~mL}$ methanol in a flask with a condenser at $60^{\circ} \mathrm{C}$ in $6 \mathrm{~h}$. Extract was subsequently filtered to remove particles, and the final volume was determined.

\subsection{Total Phenolic Contents (TPCs)}

TPCs were determined using the Folin-Ciocalteau procedure with gallic acid as standard (Singleton $\&$ Rossi, 1965). For this, $680 \mu \mathrm{L}$ distilled water, $20 \mu \mathrm{L}$ methanolic extract of pollen and $400 \mu \mathrm{L}$ of
0.2 $\mathrm{N}$ Folin-Ciocalteu were mixed and then vortexed. After 2 min, $400 \mu \mathrm{L} \mathrm{Na}_{2} \mathrm{CO}_{3}$ (10\%) was added, the mixture was incubated with intermittent shaking for $2 \mathrm{~h}$ at room tempature. Absorbance was measured at $760 \mathrm{~nm}$ and TPC concentration was calculated as mg of gallic acid equivalents per gram of g sample.

\subsection{Total Flavonoid Contents (TFCs)}

Total flavonoid contents were determined by aluminium chloride colorimetric assay which was read at $415 \mathrm{~nm}$. Quercetin was used as the standard for the preparation of the calibration curve. The final results were expressed as $\mathrm{mg}$ of quercetin equivalents $(\mathrm{QE})$ per g pollen sample (Fukumoto \& Mazza, 2000).

\subsection{Proanthocyanidin Content (Condensed Tannins)}

Proanthocyanidin contents (condensed tannins) of the analyzed sample were determined with a spectrophotometric assay previously described by Julkunen-Tiitto, (1985). This method is also known as vanillin method. To apply this assay, various concentrations of $25 \mu \mathrm{L}$ methanolic pollen extracts, $750 \mu \mathrm{L}$ of $4 \%$ vanillin dissolved in methanol and also $375 \mu \mathrm{L}$ of concentrated $\mathrm{HCl}$ were mixed. After $20 \mathrm{~min}$ incubation, the absorbance of this mixing was measured at 500 $\mathrm{nm}$. Catechin was used to establish the standard curve $(0.02-1 \mathrm{mg} / \mathrm{mL})$. The results were expressed as $\mathrm{mg}$ catechin equivalent to $(\mathrm{CE}) / \mathrm{g}$ pollen sample. 


\subsection{Ferric Reducing Power (Frap)}

For this antioxidant test, a freshly prepared FRAP reagent was used, which the preparing methodology of this reagent was detailed given by a previous study (Benzie \& Strain, 1996). Briefly, $3 \mathrm{~mL}$ freshly FRAP reagent and $100 \mu \mathrm{L}$ of methanolic sample was mixed and incubated in 4 $\min$ at $37^{\circ} \mathrm{C}$, and the absorbance was read at 595 nm. FRAP values were expressed as $\mu \mathrm{mol}$ $\mathrm{FeSO}_{4} .7 \mathrm{H}_{2} \mathrm{O}$ equivalent of $\mathrm{g}$ pollen sample.

\section{RESULT AND DISCUSSION}

Flower pollen is a product hosted in the anthers of flowers. It is produced from the male organs to fertilize the female organs (Orzáez Villanueva, Díaz Marquina, Bravo Serrano, \& Blazquez Abellán, 2002). The vary of botanical and geographic origins is responsible for the differentiation of the flower pollen's composition (Aličić, Šubarić, Jašić, Pašalić, \& Ačkar, 2014). Honey bees agglutinate the different pollen grains on the hind legs and they carry to their hive by mixing their secretions and also a small percentage of nectar (Bilisik, Cakmak, Bicakci, \& Malyer, 2008). The general composition of bee pollen is carbohydrates (13-55\%), crude fibers (0.3-20\%), proteins (10-40 \%), and lipids (1-10\%), respectively (Villanueva et al., 2002). Besides these major components, many minor ones are seen such as minerals and trace elements, vitamins and carotenoids, phenolic compounds, sterols, and terpenes (Bogdanov, 2017). Especially, polyphenol substances mainly phenolic acids and flavonoids play an important role in the biological processes such as antioxidant, antiaging, anticarcinogen, antiinflammatory etc. (Aličić et al., 2014; Can et al., 2015; Zillich, SchweiggertWeisz, Eisner, \& Kerscher, 2015). Here, the current study was based on phenolic compounds related to the antioxidant characterization. It can be seen many assays to determine the antioxidant capacity according to the literature. When compared to each other, the total capacity assays summarized by total phenolic contents (TPCs) and total flavonoid contents (TFCs) give a more general idea for antioxidant properties than other specific methods. Proanthocyanidin contents and ferric reducing power (FRAP) just like emphasized by this work can be seen as a more specific methodology. As showed in Table 1, the antioxidant data were given.

Table 1. Applied assays for analyzed pollen

\begin{tabular}{|c|c|c|}
\hline Assays & Units & Result* \\
\hline $\begin{array}{l}\text { Total Phenolic } \\
\text { Content }\end{array}$ & (mg GAE/g sample) & $6.33 \pm 0.11$ \\
\hline $\begin{array}{l}\text { Total Flavonoid } \\
\text { Content }\end{array}$ & (mg QE/g sample) & $1.88 \pm 0.02$ \\
\hline $\begin{array}{l}\text { Proanthocyanidin } \\
\text { Contents }\end{array}$ & (mg CE/g sample) & $0.86 \pm 0.00$ \\
\hline FRAP & $\begin{array}{l}\begin{array}{l}(\mu \mathrm{mol} \\
\text { sample })\end{array} \\
\mathrm{FeSO}_{4} .7 \mathrm{H}_{2} \mathrm{O} / \mathrm{g}\end{array}$ & $72.38 \pm 0.21$ \\
\hline
\end{tabular}

Briefly, the result of total phenolic content (TPC) of pollen sample was determined as $6.33 \pm 0.11 \mathrm{mg}$ GAE/g pollen, total flavonoid content was $1.88 \pm 0.11 \mathrm{mg} \mathrm{QE} / \mathrm{g}$ sample, proanthocyanidin content was $0.86 \pm 0.00 \mathrm{mg} \mathrm{CE} / \mathrm{g}$ sample, finally, FRAP was $72.38 \pm 0.21 \mu \mathrm{moL} \mathrm{FeSO}_{4} .7 \mathrm{H}_{2} \mathrm{O} / \mathrm{g}$. There was a limitation to our study in terms of sample numbers. It was studied and evaluated with one sample. It is well-known that it assumed as a 
fixed nearly the same properties in all bee pollen samples however it was absolutely avoided generalization in the evaluation.

According to the current results, our data were actually lower than previous studies (Harif Fadzilah, Jaapar, Jajuli, \& Wan Omar, 2017; Vasconcelos, Duarte, Gomes, da Silva, \& López, 2017). Vasconcelos et al. (2017) publish a study to assess the influence of botanical origin on the physicochemical composition and antioxidant potential of pollen samples from Apis mellifera from the meso-regions of Brazil during a dry season. They found that the phenolic constituents of pollens were exactly affected by the season. In that study, although there were high results in terms of total phenolic, the lower ones were also recorded as $7.57 \pm 2.45$. Hence, this result was nearly similar to the current study.

Aličić et al., (2014) reported that only flavonoids of a certain structure and particularly hydroxyl position in the molecule, determine antioxidant properties. Generally, the qualitative and quantitative of flavonoids depend on the differentiation of floral and location situations just as all phenolic compounds (Can et al., 2015). Because of these explanations, the having of the lower total flavonoid degree of the analyzed sample was seemed as normal. That meant our sample did not include specific flavonoid compound, it needed to achieve some advanced analysis just like chromatographic determination to support our result.
There has not been any condensed tannins are a group of the member of the polymeric flavonoid molecules that are found in higher plant species (Robbins, Bavage, Strudwicke, \& Morris, 1998). Also they responsible for many bioactivities such as antitumor, antimicrobial, and antioxidant (Yılmaz, Yıldız, Kılıç, \& Can, 2017). So, it was a reality that $0.86 \mathrm{mg}$ catechin equivalent per one gram sample was so precious result for us. It has not been met with any study which includes proanthocyanidin contents of bee pollen in the literature. For this reason, there was a limitation to compare our results with any study.

FRAP method is based on electron transfer and regarded as accurate markers of total antioxidant power because total reducing power is defined as the sum of the reducing powers of the individual compounds contained in a particular sample (Aliyazicioglu et al., 2016). Ulusoy \& Kolayli, (2014) studied some Anzer bee pollen, they found the FRAP value range from 11.77 to $105.06 \mu \mathrm{mol}$ Trolox/g pollen. Another study from Yildiz et al., (2013) revealed that a pollen sample supplied from Zonguldak was $82.31 \pm 2.41 \mathrm{mM}$ Trolox/g DW. It was seen that the units were different according to the previous studies, but Saral, Kiliçarslan, Şahin, Yildiz \& Dinçer (2019) utilized the $\mathrm{FeSO}_{4} .7 \mathrm{H}_{2} \mathrm{O}$ as the standard just like us and supported our results ranged from 8.69$84.89 \mu \mathrm{mol} \mathrm{FeSO}_{4} .7 \mathrm{H}_{2} \mathrm{O} / \mathrm{g}$ sample. 


\section{CONCLUSION}

According to these results, different antioxidant assays are very important to show the bioactivity degrees of any natural compounds. Here was a pollen sample study in terms of antioxidant capacity, it was found as a moderate when compared with literature. Because all bee products -bee pollen is one of them- show variability thanks to different reasons such as climatic, seasonal, botanical origin etc. Our result demonstrated that all bee-pollens whatever types can be helpful for human consumption and health owing to its antioxidant capacity.

\section{REFERENCES}

Aličić, D., Šubarić, D., Jašić, M., Pašalić, H., \& Ačkar, Đ. (2014). Antioxidant properties of pollen. Hrana u Zdravlju i Bolesti, Znanstveno-Stručni Časopis Za Nutricionizam i Dijetetiku, 3(1), 6-12.

Aliyazicioglu, R., Korkmaz, N., Akkaya, S., Ozlem Sener, S., Badem, M., Alpay Karaoglu, S., Eyupoglu, Ozan Emre (2016). Phenolic components, antioxidant and antimicrobial activities of Centranthus longiflorus $\mathrm{L}$. International Journal of Advanced Research in Biological Sciences, 3(10), 80-87. (https://doi.org/10.22192/ijarbs)

Benzie, I. F., \& Strain, J. J. (1996). The Ferric Reducing Ability of Plasma (FRAP) as a Measure of "Antioxidant Power": The FRAP Assay. Analytical Biochemistry, 239(1), 70-76. (https://doi.org/10.1006/abio.1996.0292)

Bilisik, A., Cakmak, I., Bicakci, A., \& Malyer, H. (2008). Seasonal variation of collected pollen loads of honeybees (Apis mellifera L. anatoliaca). Grana, 47(1), 70-77. (https://doi.org/10.1080/00173130801923976)

Bogdanov, S. (2017). Pollen: Production, Nutrition and Health: A Review. Bee Product Science, 1-36. Retrieved from www.bee- hexagon.net.

Can, Z., Yildiz, O., Sahin, H., Akyuz Turumtay, E., Silici, S., \& Kolayli, S. (2015). An investigation of Turkish honeys: their physicochemical properties, antioxidant capacities and phenolic profiles. Food Chemistry, 180, 133-141. (https://doi.org/10.1016/j.foodchem.2015.02.024)

Fukumoto, L. R., \& Mazza, G. (2000). Assessing antioxidant and prooxidant activities of phenolic compounds. Journal of Agricultural and Food Chemistry, 48(8), 3597-3604. (https://doi.org/10.1021/jf000220w)

Harif Fadzilah, N., Jaapar, M. F., Jajuli, R., \& Wan Omar, W. A. (2017). Total phenolic content, total flavonoid and antioxidant activity of ethanolic bee pollen extracts from three species of Malaysian stingless bee. Journal of Apicultural Research, 56(2), 130-135. (https://doi.org/10.1080/00218839.2017.1287996)

Julkunen-Tiitto, R. (1985). Phenolic constituents in the leaves of northern willows: methods for the analysis of certain phenolics. Journal of Agricultural and Food Chemistry, 33(2), 213-217.

Komosinska-Vassev, K., Olczyk, P., Kaźmierczak, J., Mencner, L., \& Olczyk, K. (2015). Bee Pollen: Chemical Composition and Therapeutic Application. Evidence-Based Complementary and Alternative Medicine, 2015, 1-6. (https://doi.org/10.1155/2015/297425)

Orzáez Villanueva, M. T., Díaz Marquina, A., Bravo Serrano, R., \& Blazquez Abellán, G. (2002). The importance of bee-collected pollen in the diet: A study of its composition. International Journal of Food Sciences and Nutrition, 53(3), 217-224.

(https://doi.org/10.1080/09637480220132832)

Pasupuleti, V. R., Sammugam, L., Ramesh, N., \& Gan, S. H. (2017). Honey, Propolis, and Royal Jelly: A Comprehensive Review of Their Biological Actions and Health Benefits. Oxidative Medicine and Cellular Longevity, 2017(1259510), 1-21. (https://doi.org/10.1155/2017/1259510)

Robbins, M. P., Bavage, A. D., Strudwicke, C., \& Morris, P. (1998). Genetic Manipulation of 
Condensed Tannins in Higher Plants: II. Analysis of Birdsfoot Trefoil Plants Harboring Antisense Dihydroflavonol Reductase Constructs. Plant Physiology, 116(3), 1133-1144. (https://doi.org/10.1104/pp.116.3.1133)

Sahin, H. (2016). Honey as an apitherapic product: its inhibitory effect on urease and xanthine oxidase. Journal of Enzyme Inhibition and Medicinal Chemistry, 31(3), 490-494. (https://doi.org/10.3109/14756366.2015.1039532)

Saral, Ö., Kiliçarslan, M., Şahin, H., Yildiz, O., \& Dinçer, B. (2019). Evaluation of antioxidant activity of bee products of different bee races in Turkey. Turkish Journal of Veterinary and Animal Sciences, 43, 441-447. (https://doi.org/10.3906/vet-1901-3)

Singleton, V. L., \& Rossi, J. A. (1965). Colorimetry of total phenolics with phosphomolybdic-phosphotungstic ccid reagents. American Journal of Enology and Viticulture, 16(3), 144-158.

Ulusoy, E., \& Kolayli, S. (2014). Phenolic Composition and Antioxidant Properties of Anzer Bee Pollen. Journal of Food Biochemistry, 38(1), 73-82. (https://doi.org/10.1111/jfbc.12027)
Vasconcelos, M. R. dos S., Duarte, A. W. F., Gomes, E. P., da Silva, S. C., \& López, A. M. Q. (2017). Physicochemical composition and antioxidant potential of bee pollen from different botanical sources in Alagoas, Brazil. Ciencia $e$ Agrotecnologia, 41(4), 447-458. (https://doi.org/10.1590/1413-70542017414009317)

Yıldız, O., Can, Z., Saral, O., Yuluğ, E., Oztürk, F., Aliyazıcıoğlu, R., ... Kolaylı, S. (2013). Hepatoprotective potential of chestnut bee pollen on carbon tetrachloride-induced hepatic damages in rats. Evidence-Based Complementary and Alternative Medicine: ECAM, 2013, 461478. (https://doi.org/10.1155/2013/461478)

Yılmaz, A., Yı1dız, S., Kılıç, C., \& Can, Z. (2017). Total Phenolics, Flavonoids, Tannin Contents and Antioxidant Properties of Pleurotus ostreatus Cultivated on Different Wastes and Sawdust. Int. J. Sec. Metabolite, 4, 1-9. (https://doi.org/10.21448/ijsm.252052)

Zillich, O. V., Schweiggert-Weisz, U., Eisner, P., \& Kerscher, M. (2015). Polyphenols as active ingredients for cosmetic products. International Journal of Cosmetic Science. Blackwell Publishing Ltd. 